فاعلية برنامج تدريبي موجه قائم على بدوث الفعل لتنمية الفهم الجمالي

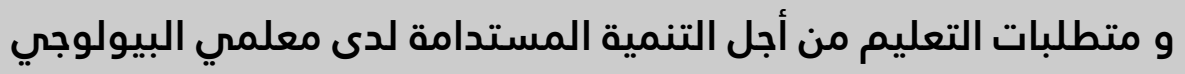
بالمرحلة الثانوية

/ أماني محمد عبدالحميد أبوزيد 
فاعلية برنامج تدريبي موجه قائم على بحوث الفعل لتنمية الفهم الجمالي و متطلبات التعليم من أجل التنمية المستدامة لدى معلمي البيولوجي بالمرحلة الثانوية د. أمـاني محمد عبد الحميد أبوزيد مدرس المناهج وطرق تدريس العلوم، كلية التربية جامعة عين شمس، مصر، dr.amany_abuzied@yahoo.com

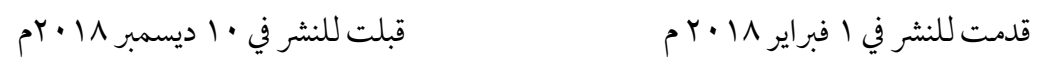

ملخص البحث: مهدف البحث الحالي إلى تعرف فاعلية برنامج تدريبي موجه قائم علن بحوث الفعل في ضوء أبعاد الفهم الجمالي ومتطلبات التعليم من أجل التنمية المستدامة لمعلمي البيولوجي بالمرحلة الثانوية بإحدى المدارس الدولية بمصر، وتمثلت مشكلة البحث في "ضعف المهارات الأدائية اللازمة لمتطلبات الفهم الجملالي والتعليم من أجل التنمية المستدامة لدئ معلمي البيولوجي" وفقًا لتطبيق أدوات البحث علن عينة تتكون من ( • ) من معلمي البيولوجي في المدارس اللغات والدولية بمصر، مما أدى إلى ضعف تدريس البيولوجي في ضوء أبعاد الفهم الجمالي ومتطلبات التنمية المستدامة كأحد المعايير الدولية لتدريس العلوم. وللتغلب علن هذه المشكلة تم بناء قائمة بالمهارات الأدائية اللازمة للفهم الجملالي والتربية من أجل التنمية المستدامة، ثم بناء برنامج تدريبي بنظام بحوث الفعل لمعلمي البيولوجي في ضوء هذه المهارات. كما تم إعداد أدوات البحث والمتمثلة في محتوكن البرنامج التدريبي، وأدوات القياس الكيفية والكمية وهي علن التو الي: ( 1 ا-خريطة ذهنية: أداة كيفية ذات أبعاد قابلة للقياس لمدئ إلمام المعلمين بأبعاد الفهم الجملالي ومفاهيمه وعلاقته بمتطلبات التعليم من أجل التنمية المستدامة. ب-نموذج التعلم القائم على المشروع: وهو أداة كيفية ذات معايير محددة من قبل الباحثة لقياس قدرة المعلم على تقديم نموذج لتصميم أحد موضوعات البيولوجي في شكل مشروع قائم علن أبعاد الفهم الجمالي والتعليم من أجل التنمية المستدامة، كذلك خطة بحث فعلية لتطبيق ذلك. r-مقياس تأملي: أداة كيفية ذات ثلاث أسئلة مفتوحة النهاية لتوثيق رأي المعلمين في اشراكهم في بحوث الفعل من خلال البرنامج التدريبي الموجه القائم علن الفهم الجمالي والتربية من أجل التنمية 
المستدامة. r-مقياس الفهم الجملالي: هو أداة كمية بهدف إلى قياس مدى اكتساب المعلمين لمفاهيم وأبعاد الفهم الجملالي في البيولوجي. ع-مقياس التربية من أجل التنمية المستدامة: أداة كمية يهدف إلى قياس مدى اكتساب المعلمين لمفاهيم وأبعاد التربية من أجل التنمية المستدامة). ت تم اختيار مجموعة البحث و التي تكونت من (0) معلمين بيولوجي بإحدى المدارس الدولية بمصر، وطبقت الأدوات علن مجموعة البحث. وتوصلت نتائج البحث إلنى وجود فروق دالة احصائيًا عند مستوى(0 • , •) بين متوسطي درجات المعلمين في التطبيق القبلي والبعدي لكل من الخريط الذهنية، وكذا مقياس الفهم الجمالي ومقياس التربية من أجل التنمية المستدامة، كما تم تحليل البيانات الخاصة بالأداتين الكيفيتين "نموذج التعلم القام علن المشروع" و "المقياس التأملي" تحليلًا وصفيًا كيفيًا وتوصلت الباحثة إلى فعالية البرنامج التدريبي لمعلمي البيولوجي في تحقيق أهداف البرنامج التدريبي. و وأوصئ البحث بإعادة النظر في برامج إعداد معلمي العلوم/ البيولوجي وإعادة تدريب الطلاب المعلمين، والمعلمين في الخدمة وفق أبعاد الفهم الجملالي والتربية من أجل التنمية المستدامة وكذلك إشراك المعلمين في بحوث الفعل في عديد من التخصصات لما لها من تأثير في الفهم ذو المعنى والمشاركة الفاعلة للمعلمين في تحقيق الأهداف التربوية المطلوبة. الكلمات الدلالية: الفهم الجمالي، التربية من أجل التنمية المستدامة، بحوث الفعل 


\title{
Oriented program through Action Research for Biology teachers to develop their meaningful Aesthetic Understanding of biology and the
} Education for Sustainable Development requirements

\author{
Dr. Amany Mohamed Abuzied \\ Lecturer of Curricula and instruction of Science Education, College of Education, Ain \\ Shams University, Egypt. dr.amany_abuzied@yahoo.com
}

Received 1 February 2018

Accepted in 10 December 2018

\begin{abstract}
This study reports on Egyptian Secondary- stage (high school) Biology teachers' experiences in action research through an oriented- training program focus on aesthetic understanding and education for sustainable development (ESD). The Program applied in the second/ spring semester of the academic year 2017/2018, fourhours weekly per 5 weeks. The research problem stated in the shortage of acquiring aesthetic understanding and Education for sustainable development requirements for biology teachers. Throughout the research, five teachers were trained through the oriented program to promote their meaningful aesthetic understanding of biology and acquire the ESD requirements through action research in their classrooms. The framework that guided this study based on experiential, constructivist and transformative learning theories known collectively as "Exp-Con-Tran". A mixed methods were used where teachers' responses through qualitative and quantitative tools that are: Firstly: The Qualitative instruments, which are: 1- A Mind Map in which Biology teachers were asked to construct a mind map of aesthetic understanding concepts and ESD requirements before and after engaging in the action research. 2- Project- based learning Form: A qualitative tool with determined criteria to assess the ability of biology teacher after learning the oriented program to design a topic from biology curriculum in a project form according to the aesthetic and ESD pedagogy with passion development requirements. 3-Reflection Questionnaire (RQ): a qualitative tool with three Open-ended questions documented the teachers' perspectives on how they received their experience through the action research stages. Secondly: The quantitative instruments, which are 1- An


aesthetic understanding questionnaire 2-An Education for Sustainable Development Questionnaire. The former was to probe the cognitive of the participants had in relation to the concepts of aesthetic understanding before and after involving in the action research program. The second instrument used to identify participants' attitudes towards teaching for ESD and their knowledge of classroom pedagogical practices. Statistical data analysis using Statistical Package for the Social Sciences (SPSS 9) applied to detect the significance difference between the mean score of teachers' pre and post results in (Mind map, aesthetic questionnaire and ESD questionnaire). The results indicate that teachers in their post-results recorded better cognitive organization for the concepts of aesthetic understanding in biology; positive attitudes towards teaching for ESD classroom-teaching practices at (0.05) level. The results of reflective questionnaire and the Problem- based form analyzed qualitatively and recorded positive attitudes in the post results. Involvement in the action research projects where teachers were experiencing, reflecting, conceptualizing, constructing, acting and transforming may be responsible for these results, so it is recommended to involve teachers more in the action researches in many fields.

Key words: Aesthetic understanding, Education for sustainable development (ESD) and Action research. 


\section{Introduction}

A large literature confirmed on the role of aesthetics, creativity, passion, beauty, and art play in the lives and learning of scientists. Scientists sometimes describe their work as beautiful and artful, citing these qualities as the motivating forces that often drive their work. An acute awareness of the beauty inherent in scientific ideas in biology and scientific discovery necessarily draws in to this study. To learn biology from this perspective, it should be introduced as an integrated act, rather than solely cognitive or solely affective subject. Aesthetic understanding is a constructivism, transformative theory derived from Dewey and Feynman theories; Aesthetic understanding teaches content and demonstrates an empowering way of perceiving and interpreting the world through science ideas.

To teach biology from the aesthetic perspective, there many questions to ask such as; how can biology education actively contribute to the severe environmental, technological and scientific challenges of our time? How should biology teachers' education meet these challenges? How can biology teaching support students' connectedness to the world? What are potential inclusions of aesthetic experience in biology education to strengthen students' grounding? How could the aesthetic understanding of the biology teachers increase their meaningful understanding of biology? These questions based on assumptions: First, that disconnectedness is a problem for students to understand the biology aesthetically, and second, that biology education and biology teachers' education have a responsibility for supporting students' need to find firm ground to understand biology aesthetically.

These assumptions made the author critically examined how to build an oriented program for biology teacher to provide their meaningful aesthetic understanding of biology, which leads to increase their aesthetic experience for biology teaching, and reflected on their sustainable- social development practices. ESD, therefore, presents a tool for achieving this vision and improving quality of life. With this in mind, this vision helps understand the world by addressing the complexity and interconnectedness of daily problems, locally and globally. 
There is a strong evidence to suggest that the Arab countries, including Egypt, are lagging behind in practices related to sustainable development until the global 2030 Agenda through "Egypt vision 2030" in September 2015 for sustainable Development, and the sustainable development goals (ENRR, 2016). Therefore, there is a need to find ways to promote ESD. Teacher education programs, whether preservice or in-service, could be a powerful start, especially through reorienting teacher education courses to address sustainability. Teachers are agents of change in any reform effort who will shape the knowledge, skills and values of future generations given the regional priorities and the need to modernize curricula to address ESD. Paradoxically, they are also viewed as major obstacles to change if their emphasis is only on factual and procedural knowledge at the expense of deeper levels of understanding through aesthetic understanding (SDSN, 2015).

This study involved biology teachers in action research to develop their aesthetic understanding and highlighted the importance of teachers in promoting ESD practices in their classrooms, and among their students. This process was enabled through the oriented program to five biology teachers whom are working at international school in Egypt.

\section{Statement of the problem}

Considering the vital roles teachers have to prepare and develop students' ability to become effective citizens in a sustainable society, biology teachers are required to apply practices that foster their aesthetic understanding, active and experiential learning approaches that are important for ESD. Courses offered at the faculty of Education, which is responsible for teacher education programs and inservice training; seem to lack courses on ESD in its holistic and futuristic perspective or prepared according to the philosophy of aesthetic understanding, as examined by the author of this study whom is work at it. This result came from a preliminary analysis of the programs offered at the undergraduate and postgraduate levels through the last researches and literatures and through the researcher investigation to Ain Shams University -faculty of education, biology students- teachers preparing 
programs. Moreover, a questionnaire was administered to a group of 25 biology teachers attending a seminar at the Department of Curricula and Instruction in order to indicate their prior knowledge of the ESD and aesthetic understanding concepts to justify and document the need for a revised program prepared according to the aesthetic understanding and ESD requirements. The questionnaire consisted of three parts; the first one is 21 likert-scale questions of three responses (Agree- NeutralDisagree) to identify the teachers' perception of aesthetic understanding. While the second part is 18 likert- scale questions, with five scale responses (Strongly agreeagree- neutral- disagree- strongly disagree) which, asked teachers about their ESD teaching practices. The last part consists of five open- ended questions asked them to reflect on their biology teaching practices. Reliability coefficients of questionnaire parts items were determined by the judgment of experts in science curricula at Ainshams University. To check its face validity, it applied on a random sample of 50 biology teachers, to put it in its final shape (Appendix 1). Statistical package (SPSS) was used to check its reliability and validity. Cronbach's alpha for all parts scale was $=0.88$ and internal consistency was $=0.79,0.72$ and 0.72 respectively for each part, which indicate that it has a significant at the level of (0.01). Results illustrated that the majority of the teachers responded negatively, as they either agreed or strongly agreed that they lack aesthetic understanding concepts and ESD requirements. They also identified that their current teaching practices lacked aesthetic understanding, and the practices of ESD. Their responses analyzed with parametric statistics tool (SPSS Onesample T- test) with a 50\% criterion, the results showed that there is not a statistical significant differences at the level of (0.05) compared with the 50\% criterion shown in table (1) as follow: 
Table (1) comparison of Biology teachers' awareness of the aesthetic understanding and ESD pedagogy in biology teaching with $(50 \%)$ criterion, $\mathrm{T}$ significance value is $(0.05)$ when it is 40.75 or more

\begin{tabular}{|c|c|c|c|c|c|c|}
\hline Dim. & measurement & $\mathbf{N}$ & Mean & STDV & t-value & Sig. \\
\hline \multirow{2}{*}{ Part1 } & sample & 25 & 40.2 & 2.4664 & \multirow{2}{*}{24.93} & \multirow{2}{*}{0.00} \\
\hline & Criteria (50\%) & 25 & 52.5 & - & & \\
\hline \multirow{2}{*}{ Part2 } & sample & 25 & 33.04 & 6.5732 & \multirow{2}{*}{9.09} & \multirow{2}{*}{0.00} \\
\hline & Criteria $(50 \%)$ & 25 & 45 & - & & \\
\hline \multirow{2}{*}{ Part3 } & sample & 25 & 5.84 & 0.8 & \multirow{2}{*}{35.62} & \multirow{2}{*}{0.00} \\
\hline & Criteria $(50 \%)$ & 25 & 12.5 & - & & \\
\hline \multirow{2}{*}{ Total } & sample & 25 & 79.08 & 6.9097 & \multirow{2}{*}{22.37} & \multirow{2}{*}{0.00} \\
\hline & Criteria $(50 \%)$ & 25 & 110 & - & & \\
\hline
\end{tabular}

Based on these results, it seemed central to fill in a gap in the courses presented at the faculty of Education and the professional development programs of teachers in order to develop the students- teachers or in-service teachers with aesthetic understanding of biology and develop their ESD practices in their classrooms. An oriented program based on aesthetic understanding dimensions and ESD requirements were presented to five biology teachers through an action research at one of the international schools in Egypt to investigate the efficacy of it, in order to develop the teachers' aesthetic understanding of biology and their ESD practices in their classrooms by answering the following research question:

What is the efficacy of oriented program through action research for biology teachers to develop their aesthetic understanding in biology and the ESD requirements? 
A number of sub-questions arise from the main question to formulate the stages of the study:

1. What is the biology teachers' perception of aesthetic understanding and ESD?

2. What is the context of oriented program based on the aesthetic understanding and EDS' requirements pedagogical practices?

3. What is the effectiveness of the oriented program to develop the biology teachers' aesthetic understanding?

4. What is the effectiveness of the oriented program to develop the education for sustainable development requirements for biology teachers?

5. How do biology teachers perceive their experiences through action research to develop meaningful aesthetic understanding in teaching biology?

Study objectives: The study aimed to:

1. Provide a training program through action research of basic aesthetic understanding and ESD requirements to biology teachers to investigate their meaningful aesthetic understanding to biology and their ESD practices in their classroom.

2. Investigate the efficacy of the oriented program to develop the biology teachers' aesthetic understanding through aesthetic understanding questionnaire attributed to their action practices.

3. Investigate the efficacy of the oriented program to develop the biology teachers' ESD skills through ESD questionnaire attributed to their action practices.

4. Investigate the impact of the oriented program on the teachers' reflections through the reflective questionnaire. 
Study importance: The study is seeking to:

- Design an oriented program that could be used by curriculum designers or teachers to employ aesthetic understanding in science/ biology teaching.

- Promoting teachers in helping their students to pleasantly acquire the scientific concepts, and develop their aesthetic understanding through the oriented program.

- Also, help teachers to enhance their ESD skills in their classrooms, which could be reflected positively on their students through the oriented program.

- Introduce a model of action research in biology teaching that could help the researchers in the science-teaching field.

- Introduce an aesthetic understanding questionnaire and ESD questionnaire that could be used by the researchers in the field.

\section{Methods:}

- Research design

A mixed method was employed through descriptive analytical approach, which used to obtain information concerning the research problem situational variables, and carrying out analysis using quantitative and qualitative data. . This was mainly in order to deal with the processes proposed at the different stages of the study that answer the research questions and address its main aims. The theoretical framework that guided this study was the ExConTra learning model (Makrakis \& KostoulasMakrakis, 2012) where there is an emphasis on three major learning theories, namely, experiential, constructivist and transformative learning theory. The model consists of six independent but interconnected components. These are experiencing, reflecting, conceptualizing, constructing, acting and transforming, all of which are found throughout the process of action research. Through action research, teachers are likely to become aware of their own beliefs and practices, expand their commitment to develop a variety of teaching methods and renew their interest in learning about teaching. It is therefore a means to systemic inquiry into daily teaching practices, where teachers reflect on teaching on a deeper level (Kraft, 2002). Through such activity, teachers' roles change within a new perspective as they become active 
knowledge producers who continuously develop practical knowledge while solving problems in, and dig deep through aesthetic understanding dimensions. Moreover, they become part of the educational reform process as empowered agents to change and initiate change and apply new ideas. Furthermore, action research can bridge the gap between theory and practice because it helps teachers to understand the purpose of educational research and, in turn, informs educational theory of the reality of the classroom (Briscoe \& Wells, 2002). In addition, teachers are empowered by having ownership of their professional knowledge.

\section{- Profile of the participants}

Purposive Sampling used to select participants of this study, as they were enrolled in an oriented program; which needs affective biology teachers whom are working in Egyptian international schools. They should be flexible to apply the philosophy and pedagogy of the program through action research. In addition to the limited restrictions of most international schools that put on their teachers practicing. The oriented program presented at the faculty of Education that the author of this study work. Five biology teachers whom are working in Egyptian international school selected to apply their required knowledge and experience on two topics of biology in their school spring semester. Demographic data were collected that specified gender, age range, years of experience in biology teaching and experience. There were two male teachers and three female biology teachers enrolled in the oriented program to investigate whether the sex agent has impact on the teachers' results or not through some of the qualitative analysis.

\section{- Terms and Procedural Definitions}

\section{1- Aesthetic understanding}

Aesthetic understanding is the blending of cognitive and discursive waysof knowing with all important affective and artistic ways-of-knowing into a more unified, holistic, human understanding, and aesthetic dimensions include the power of new knowledge to transform us, to be dramatic, compelling, and to be unifying then, add coherence to our understanding of the world (Girod, Rau\& Schepige, 2007). 


\section{2- Education for sustainable development (ESD)}

ESD is far more than teaching knowledge and principles related to sustainability. ESD, in its broadest sense, is education for social transformation with the goal of creating more sustainable societies. It touches every aspect of education including planning, policy development, program implementation, finance, curricula, teaching, learning, assessment, administration, aims to provide a coherent interaction between education, public awareness, and training with a view to creating a more sustainable future, ESD is a skills-oriented paradigm in education which meets the requirements of central educational theories (UNESCO, 2012).

\section{3- Action research}

It is a form of enquiry undertaken by participants in social situations to improve the rationality and justice of their own social or educational practices. Moreover, they reflect on their understanding and the situations in which these practices are carried out (Hine, 2013).

\section{- Limitations of the research}

1. Human limits: the study is limited to High school biology teachers, where a group of (5) teachers in Notion international school were enrolled in the study.

2. Place limits: the study was conducted in Faculty of education- Ain-shams University and applied at the previous school.

3. Time limits: the study conducted during the second/ spring semester of the academic year 2017/2018.

\section{- Procedures}

Reoriented program based on aesthetic understanding philosophy and ESD requirements introduced to high school biology teachers. The purpose was to reorient a program based on aesthetic understanding philosophy and ESD pedagogy in educational context, and mainly adopt teaching methodologies, and hands-on to involve the participants in practices that help them to develop their aesthetic understanding in biology and ESD skills in their classrooms practices. The main 
method in revising the program was by the "infusion approach" that permits to address aesthetic understanding and ESD pedagogies by teaching with a different perspectives and philosophy without changing the meaning and aim of the original version (Reason, 2007). Therefore, the program was guided by the author's philosophy to change and reflect, taking into consideration that sustainability and aesthetic understanding demand transformation, which involves a radical shift of the biology teachers' perception of meaningful aesthetic understanding of biology in a sustainable development requirements context. To make sure that the orientedtraining program followed an acceptable structure in terms of program design, program objectives and description were then stated and reviewed from specialists in biology education at Ain- Shams University. The program was a four-hour weekly course for 5 weeks offered in the beginning of second term/ spring semester in the academic year 2017/2018.

Biology teachers were asked throughout the study to reflect on their perspectives and the way they deal as an artist to redesign the biology curriculum. They particularly apply aspects of ESD relate directly to biology in their classrooms practices. Teachers were also asked to reflect on their classroom teaching practices and then develop action projects to incorporate the main issues of aesthetic understanding in their daily pedagogical teaching. This was done purposely by reflective questionnaire to provide teachers with opportunities for transformative learning as "agents of change" in biology educational field.

For the action research, this was done collectively through the use of the meaningful learning environments such as: a) engaging and challenging learners; b) stimulating dialogue and social interaction; c) learning by exploring, discovering, doing and reflecting; d) constructing personal and collective representations of meaning, and e) supporting discourse in dealing with learning problems (Makrakis, 2011). Biology teachers in this study developed research projects (project- based learning) that started by identifying tools of aesthetic understanding focus on ESD requirements then going through action plan to implement it in their classrooms, then they reflected on their practices. 
The action plan projects were analyzed qualitatively according to rubrics of the "Project- based Form" developed by the author of the study, illustrated one biological topic prepared by the participants to teach biology based on aesthetic dimensions and ESD skills. Qualitative data analyzed to detect the efficacy of the oriented program to help the teachers to design a plan for the biology topic according to the aesthetic understanding and ESD requirements.

\section{Theoretical framework and literature review}

Orienting Biology education towards aesthetic understanding and ESD requires a shift in both the content and contextual approaches in biology teaching, as well as in the pedagogies (Burmeister et al., 2012). Every student needs planned, aesthetic education in order to influence the experiencing, feeling and enjoying of beautiful things in his world. Since our curricula neglect the affective dimensions of the student's personality (emotions, feelings, art sense etc.), it is one of the most important tasks of the sciences full of art like biology to fill in this gap that could increase students' passion for biology learning and meaningful understand to his world. In the case of Biology education, there have also a number of attempts to identify the potential contribution of Biology curriculum to ESD (for instance, Wellington, 2003; United Nations Educational, Scientific and Cultural Organization [UNESCO], 2014). There are suggestions that the aims of school biology education need to be examined with respect to affect domains, in addition to socio-scientific (Holbrook, 2009). Others have seen ESD as one of the 21st century skills that incorporates a number of sustainable development issues within its vision of scientific literacy (Summers \&Childs, 2007). When it comes to biology teachers, envisioning biology teaching for SD as inquiry and aesthetic understanding through its concepts became urgent. In Egypt, there are rare researchers that illustrate aesthetic understanding in biology teaching. However, there is no researchers dealt with how to teach biology from the aesthetic perspective and using its pedagogy blended with ESD ones according to the limit of author's knowledge. Studies that support teachers' involvement in action research on students' learning include, for instance, Hammer and Schifter (2001) and van Zee, Lay and Roberts (2003), while those that are 
specifically related to biology teachers and action research in terms of a means to professional development include, for instance (Ponte, Ax, Beijaard and Wubbels, 2004). Action research in this study was used as a means for participants to understand, improve and reflect on their own practices in actual situations. Through the process of engaging in action research, teachers gain deep insights into how they are working whilst looking forward to their future practices that enable them to transform in their thoughts, feelings and actions in a paradigm shift. This study illustrates its vision through two dimensions: Aesthetic understanding and Education for sustainable development.

\section{First: Aesthetic Understanding}

Hobbs and Kelly (2015, p. 57) describes Dewey's philosophy in which he refuses to separate the cognitive and affective aspects of human nature. According to Dewey's philosophy, the experience acts as agent in his both cognitive and affective dimensions. He termed this "aesthetic experience" signifying "experience as appreciative, perceiving and enjoying". Dewey described the quality of experience as having two aspects: the first aspect: that "the individual actively perceives an

experience: "not absence of desire but thorough incorporation into his perception". The second aspect he captures as" "continuity of experience"; where one experience lays the foundation for how we qualify and "live" future experiences. Wickman (2006, p.96) further elaborated that in an aesthetic experience the cognitive and affective are intrinsically linked to speak of an emotional or affective response to that knowing. The effect of an experience is individually determined during its continuity. There is transaction between person and world, between experiencer and experienced. This is a departure from our current and overwhelmingly common cognitive, rational perspectives on teaching and learning. Attention here is extended to include emotions, actions, and perceptions. A person who truly learns exits transformed, not just of mind but also of heart, eye, and body. Education should leave us different understanding more, seeing differently, and willing to act in accordance with these differences (Hobbs\& Kelly, 2017, pp. 70-75). 
Science education researchers have been applying Dewey's ideas about aesthetics to classroom teaching and learning. For example, Wickman (2006) describes science, and science teaching and learning from the perspective of practical epistemology suggesting that meaning is better situated in action rather than as in representations. Wickman (2007) describe science teaching and learning as being driven by moments of aesthetic experience. Both studies argue that a linkage among the cognitive, rational and the aesthetic enriches learning and doing. Similarly, Girod et al. (2003) argue for attention to the beauty of scientific ideas and the role that this beauty can play in assisting student learning. The authors refer to learning that is linked to aesthetic dimensions as teaching and learning for aesthetic understanding. The aesthetic dimensions include the power of new knowledge to transform us, to be dramatic and compelling, and to be unifying or to add coherence to our understanding of the world. Following on these ideas, Pugh and Girod (2007) offered a discussion of the pedagogical strategies, derived from Dewey's aesthetic theory, useful in scaffolding aesthetic science learning. The strategies include: (a) crafting ordinary science content into important and powerful ways of seeing the world; (b) modeling the power of these science ideas to transform our lives, and; (c) scaffolding students' efforts to live differently because of these new ideas.

An aesthetic experience changes the way we see the world and our place in it. An aesthetic experience combines conceptual knowledge with a deep awareness and appreciation for the inherent "beauty and power of ideas" (Pugh and Girod, 2007, p. 12). This means that more knowing in aesthetic form causes a transformation in the way we experience or perceive the world. Because of this change in perception of both the world, and ourselves we invariably develop a renewed (or new) excitement and interest in the world around us. It is almost like a light switching on inside our thoughts to understand it more clearly, that were lacking prior to the transformation (Pugh and Girod, 2007, p.13). Moreover, this also matched with Gallas, Gregory\& Lemke perspectives on understanding to a Deweyan vision, They argued that aesthetic perspective allows us to blend cognitive and discursive ways-of knowing 
with all important affective and artistic ways-of-knowing into a more unified, holistic, human understanding (as cited in Girod, Rau\& Schepige, 2007, P.39).

Song (2010) described Dewey's criteria for an "educative experience" that included not only learning by doing; but also involved integrating the unique experience with mind and emotion and enabling it to continue until fulfillment or until the experience "is so rounded out that its close is a consummation and not a cessation". Such an experience is a whole and carries with it its own individualizing quality and self-sufficiency (pp.98-100).

Feynman highlights the potential of wonder and inspiration as he contemplates the world around him and the complications of its inner workings. This sense of wonder opens new doors and further questions and is the beginning of a curiosity that inspires more questions. Science, he suggests, helps us find answers to some of the most awe-inspiring questions we have about nature. It is not a rigid method, or stuffed with facts and information that we need to memorize to pass an exam; but, rather, a rich and exciting process, an adventure and a journey to solve the mysteries of the world (as cited in Mehta, 2016, p.83).

Mehta (2016) mentioned that there is one educational researcher called "Mark Girod" argued that the aesthetic experience is not just restricted to the arts, but is an integral part of doing and learning science as well. He suggested that by building on the emotional and affective elements of doing science, we could motivate our students to wonder more deeply about nature and science, stimulate their curiosity and interest, and thus transform their experience of learning science (p.84).

In his research, Mark studied two 4th grade science teachers. One of these teachers was an experienced and accomplished teacher who taught science in the traditional way, focusing on facts and conceptual understanding. The other teacher, was also an experienced teacher, but with a different focus. His class was designed to foster excitement and interest by organizing content around the power ideas have to inspire and renew perception, providing opportunities for students to experience the world in new ways that consistently highlighted the aesthetic and artful aspects of 
science. For example, conducting a class in a garden, while admiring the beauty of flowers, and framing questions that help explain, say, where a flower gets its color?, how they grow?, why they organized in such a way? (Metha, 2016, p.88).

Mark's research showed that at the end of the day, students in the Second teacher class not only performed better than the students is in the first teacher class on standardized tests, but also showed greater engagement with scientific ideas speaking about how they had discussed these ideas with their family and friends outside of the classroom. In short, they were drawn to wonder, inspired to discuss it with others, and enjoyed seeing the world through the lens of scientific ideas.

One of the implementation method is to consider knowing what your students care about - getting to know their personal preferences and interests opens a window into their lives, also design a range of inspired activities in the classroom to facilitate emerging aesthetic understanding and new ways of seeing the world. Then we could highlight those aspects of science that intersect with students lived experiences, in ways that they may have never thought of before. This makes the concept come alive in their minds, enriching daily life.

This sense of engagement and passion is often in stark contrast to how many students in school think about biology. Biology is often seen as being full of facts, mindless activities and, thus, quite dull and boring. To be clear, we are not beauty and wonder of biological ideas, because if we took some of the aesthetic elements that scientists speak of and bring them to the forefront of teaching biology, students would respond differently to what they were learning, and change their ideas of biology, and enjoy studding it.

The aesthetic understanding of the natural world is in line with biology education, most phenomena have an aesthetic biological dimension, the curricular question concerns whether the natural world itself is presented to the students (Hadzigeorgiou \& Schulz, 2014, p.1964). Biology often fills with abstract concepts such as :( Classification, Energy transformation in organisms, Genes\& DNA, Metabolisms, Enzymes, and Neurons) that could be hard to imagine and keep the 
concepts. So, to perceive beauty in these concepts, we need situations in which these concepts are embedded (e.g., Human population and Extinction, Venter artificial cell, unfortunately crashed airplane accident, Human genetic bank ethics, Aerobic cell respiration in gym, A flash of lightning in the cell, Telepathy: how could it happen?....). In other words, we need to select phenomena and situations, which 'aesthetically' exemplify the concepts to be introduced. However, because a sense of wonder, evoked through an aesthetic appreciation of these scientific phenomena, students become aware of the significance of biological and appreciate the scientific beauty of it, and develop their environmental awareness, which may be the base block of sustainable development (Hadzigeorgiou \& Schulz, 2014, p. 1968).

The (NASA, 2012) conference "The Earth as Art" collection, confirmed the idea that aesthetic appreciation can help raise awareness, by presenting the diversity and beauty of the planet, and also by revealing features and patterns, which are not visible to the naked eye. Such "artistic" images of the Earth can provide excellent material to focus on in order to introduce students to natural phenomena (e.g., erosion caused rivers, volcanic eruptions...etc.) (Hadzigeorgiou, Kampouropoulou, \& Fokiali, 2015, 745-752).

In cross-curricular art-biology integration, both beauty and sense experience could be emphasized. It becomes a problem if aesthetic understanding reduces aesthetic to "how student talk aesthetically in biology class" Wickman (2006, p. 22), presupposing that aesthetic experience can be fully verbalized. More relevant is the notion of wholeness in "trans disciplinary sensibility" Kagan (2011, p. 221), a sensibility that can be fostered in various disciplines and subjects. A fruitful integration of aesthetic experience and conceptual understanding in biology teaching is crucial for developing an aesthetic-sensitive biology education, which depends on teachers whom have the aesthetic understanding and passion to teach biology.

Teachers should strive for aesthetic experiences with beauty and aesthetic appreciation of biology ideas. They must develop both the scientist and the artist within them. Since, Biology as a science discipline is not only the process of stepping 
back and analyzing the world with cold logic and rigorous methods. It is also stepping forward in an attempt to "get inside" of objects, events, and ideas; it involves a surrendering to experience (Girod, Twyman \& Wojcikiewicz ,2010, p.820).

Howitt (2007) referred to pre-service teachers, whom often do not have the opportunity to teach science or see science being taught before they enter teaching, haven't the aesthetic understanding of science; because they missed the real positive experience of science teaching which may increase their passion toward science, and then this will be reflected on their students P.42). This was also evident which support Hobbs\& Kelly (2017) vision when they recorded their narrative during their research; they argued that "experience became personal and aesthetic in nature when there was a shift in perception of the nature teacher role, from teacher who has to teach science to teacher who loves to learn science and help others to teach it". This change has been the professional development introducing knowledge, followed by planning, enacting, and leading changes to science teaching in school. Affirmation from peers, outcomes such as student learning and students' excitement towards science was clearly in fostering a strong sense of science teacher to see science, which reflected on his understanding of what it means to be a teacher and lead change in the school.

The aesthetic dimension of teaching is fundamental to the way we think of the science educator. Teaching varies across subjects because the subject matter differs. However, the teacher's aesthetic understanding of what it means to be a science educator based on more than content knowledge. The aesthetic dimension of teaching is fundamental to how teachers develop an appreciation for the subject they teach, the respond to the pressures of change, and make decisions about how to maximize impact through education; the possibility of "seeing science through their student's eyes" raises the pedagogical value of science.

Science educators frequently look to the science discipline for guidance as to be the important subject matter ideas, behaviors, and dispositions to guide teaching and learning. Often, science within the discipline is characterized as highly analytic, logical, objective, and methodical. Pedagogy that draws from this characterization of 
science frequently asks students to step back, to be critical observers of objects, events, and the world. However, students enhanced to use their creativity, passions, and emotions. This portrayal of science can be described using Dewey's epistemology in ways that break down false binaries such as: objective vs. subjective, logic vs. intuition, thought vs. feeling, mind vs. heart, and think vs. feel. Dewey's epistemology refuses to separate these into discrete, distinguishable acts (Girod, Rau\& Schepige, 2002, P.2).

Girod, Rau\& Schepige (2002) referred to Feynman's illustration of aesthetic understanding as experiment of one student; named "Robert" explained, "I never realized everything was moving - the earth, the sun, the moon, the stars, everything is moving and it blows me away!" Realizing he would never view the night sky the same again, Robert added, "I never thought I'd become the kind of person who talked about and thought about such deep things." Aesthetic understanding literally transforms who we are and how we see the world (P.6).

This has particular meaning for those in biology as we depend on past insights to fuel those of the future. Aesthetic understanding depends on developing a similar coherence of parts, pieces, ideas, and concepts. For example, as one learns about extinction of one species, the entire classification of species is better understood as a series of relationships and continuities. Individual animal and relationships between species merge in a unified and dramatic way, disclosing secrets, and allowing one to see the beauty inherent in the biodiversity. A deep understanding of the periodic table is quite aesthetic and leads one into future experiences with a transformed and more unified vision of chemical relationships. Aesthetic understanding similarly draws students into the world through intellectual interactions and explorations. It is common for these students to think about biology ideas outside class, to search for examples and illustrations of ideas, and to tell others about what they've learned, relishing in the excitement and engagement of looking at the world with wider eyes.

The teacher plays a unique role in teaching for aesthetic understanding. A useful metaphor for describing his job is to imagine his as an artist in a studio trying 
to shape curriculum ideas and experiences for students in artistically pleasing and aesthetic ways. His job is to position students in the path of potentially unfolding aesthetic experiences. He does this first by structuring the curriculum in ways that assist or support transformative, aesthetic experiences. He should ask students to be more imaginative and creative as they wonder about the potential of ideas. Students should ask more, "what if. . ." Style questions such as, "What if this rock could talk? What story could it tell of its travels? What happened if "Sofia" cyborg has its own decision? What will happen if the biochips become available in shops? "Students should be pushed imaginatively to explore the power of biological ideas in ways similar to Einstein's famous thought experiments. Investigating the potential of ideas to transform takes time and opportunities. Teachers must provide rich opportunities to explore, wonder, and begin to make sense of biological ideas and their power to alter our perceptions of the world teachers must model their appreciation and value for the transformative power of biology ideas (Hobbs and Kelly 2017, p.83).

Girod, et al. (2003) highlighted three interconnecting elements of aesthetic understanding: they are "compelling and dramatic," "unifying," and "transformative" (p. 578) and its relation to biology teaching:

- Compelling and dramatic nature of understanding, is relate to passion for biology teaching and learning.

- Unifying, is the learning that brings unification or coherence to aspects of the world or the subject, it should be flexible and inspiring, represents the biological concepts through "The major Global concepts", which could illustrate the relation between the biological concepts and other science, discipline.

- Transformative: Perceived transformation of the person identity and its world, this could be accepted by developing the affective domains in teaching biology, especially the artistic and aesthetic dimension. 
Aesthetic understanding can enhance teaching and SD requirements in a number of ways as mentioned in (Hobbs, 2013, p. 94), (Tytler, 2007, p.240), (Girod et al. , 2003, pp. 574-587) as follow:

- Student learning experience designed for deep meaning and aesthetic response is perhaps the most typical application of aesthetic understanding, which leads to meaningful understanding of biology concepts.

- Aesthetic understanding can be seen to underpin transformative learning, which can be psychological (changes in understanding of the self), convictional (revision of belief systems/ identity), and behavioral (changes in lifestyle) which are types of 21 century kills.

- For biology educators, creating conditions for aesthetic experiences involves identifying not only students' prior knowledge but also students' attitudes and identity in relation to biology. This leads to connectedness between biology and other science discipline

- Teaching involves creating conditions for an aesthetic experience that leads to transformation and then moving students forward in their journey by exploring things further and making them aware of the opportunities for future experiences. A continuum of experience becomes the focus of instruction rather than discrete and disconnected learning experiences. This enhances curiosity and self-learning which consider one of the SD requirements.

Second: Education for Sustainable development (ESD) requirements to secondary- stage (High schools) biology teachers and its relation with Aesthetic Understanding:

ESD is far more than teaching knowledge and principles related to sustainability. ESD, in its broadest sense, is education for social transformation with the goal of creating more sustainable societies. ESD touches every aspect of education including planning, policy development, program implementation, finance, curricula, teaching, learning, assessment, administration. ESD aims to provide a coherent 
interaction between education, public awareness, and training with a view to creating a more sustainable future (UNESCO, 2012).

One of the fashion words found in recent literatures is that of education for sustainable development (ESD). Its roots can be traced back to the 1990s at the United Nations conference in Rio de Janeiro. Since then, there have been major developments towards ESD, specifically the emphasis on ESD in the Earth Summit 2002, the United Nations Declaration of the Decade of Education for Sustainable Development (DESD) in 2005- 2014 and in Rio+20 United Nations conference on sustainable development in June 2015. In general, sustainable development (SD) is perceived as the vision for a better world in which environmental, social, economic and cultural considerations are balanced. ESD, therefore, presents a tool for achieving this vision and improving quality of life. With this in mind, a new vision of education is formed, a vision that helps understand the world by addressing the complexity and interconnectedness of daily problems, locally and globally.

There is a strong evidence to suggest that the Arab countries, including Egypt, are lagging behind in practices related to sustainable development until the global 2030 Agenda through "Egypt vision 2030" in September 2015 for sustainable Development and the sustainable development goals (ENRR, 2016). There is therefore a need to find ways to promote ESD. Teacher education programs, whether pre-service or in-service, could be a powerful start, especially through reorienting teacher education courses to address sustainability. Teachers are agents of change in any reform effort who will shape the knowledge, skills and values of future generations given the regional priorities and the need to modernize curricula to address ESD. Paradoxically, they are also viewed as major obstacles to change if their emphasis is only on factual and procedural knowledge at the expense of deeper levels of understanding (SDSN, 2015).

The Education for Sustainable Development Toolkit is based on the idea that communities and educational systems within communities need to dovetail their sustainability efforts. As communities develop sustainability goals, local educational 
systems and programs can modify existing curricula or create new programs to reinforce those goals.

Education for Sustainable Development (ESD) has been accepted as a worldwide goal in educational policy. ESD is a skills-oriented paradigm in education, which meets the requirements of central educational theories. Science and technology represent central aspects of any sustainable development, making science and technology education especially responsible for integrating ESD into teaching and learning. Implementation of ESD in science education is still insufficiently developed.

In general, sustainable development (SD) is perceived as the vision for a better world in which environmental, social, economic and cultural considerations are balanced. (ESD), therefore, presents a tool for achieving this vision and improving quality of life. With this in mind, a new vision of education is formed, a vision that helps understand the world by addressing the complexity and interconnectedness of daily problems, locally and globally.

Discussions leading to the Rio+20 UN conferences have emphasized the importance of sustainable development and the protection of the environment for future generations. The Arab world faces large-scale threats to its sustainable development and, most of all, to the viability and existence of the ecological systems for its human settlements. The dynamics of population change, ecological degradation, and resource scarcity, and development policies and practices, all occurring in complex and highly unsuitable geopolitical and economic environments, are fostering the poor prospects (El-Zien, Jabbour, TeKce,..., Hogan, 2014, pp. 458476).

Anderson and Helms (2001) have suggested that teachers remain the most important factor for educational reform. What teachers think, believe and know affects their teaching. These factors are therefore important when it comes to reform teaching practices effectively and successfully. Any educational reform and implementation can only be successful if teachers` beliefs, their prior knowledge and their attitudes seriously are taken into account when implementing reforms. 
Unfortunately, formal insights into the area of teacher knowledge, beliefs and applied pedagogies concerning ESD are rare, particularly in the context of Egyptian science education (p.5, 6).

Natural scientists have argued for the improvement of science education Such pleas reflect the growing awareness that high quality science education is required not only for sustaining a lively scientific community that is able to address global problems like "global warming and pandemics", but also to bring about and maintain a high level of scientific literacy in the general population. Getting the balance right between the purposes of enthusing enough students to go on to scientific and technological careers and giving all students an interest in, and enough knowledge of science and technology so as to appreciate the importance of science and technology in society, is perhaps the major science education issue facing all countries today. This suggests that the aims for school science curricula need to be examined, especially with respect to social relevance and hence sustainable development. Equipping young persons to participate in the big socio-scientific issues of today (for example, food scarcity, poverty alleviation, HIV/AIDS/ peace building, global warming, embryonic stem cell use, toxic waste disposal, sustainable development, etc.) makes good sense in the compulsory years of education.

There is no doubt that effective education can serve as a vehicle for solving global problems. The problem centers on how to achieve education that is more effective. We believe that science education would greatly benefit from incorporating the lessons of cognitive science and contemporary ethology to provide a framework for explaining human behavior grounded in evolutionary theory. According to such a perspective, humans collectively produce and reproduce their environment through their actions and are therefore capable of acting responsibly for a sustainable future.

Cognition does not exist outside the life process that in its very nature is a material, practical process. The reflection of reality arises and develops in the process of the development of real ties of cognitive people with the human world surrounding them. It is defined by the ties and, in its turn, has an effect on their development", and 
this could not be achieved without inspired experiments integrate their cognition with their notion, awareness and emotions as illustrated by Eijick\& Roth (2007, p.2763). The watershed here is the transformation from traditional methods in teaching to new ones, so teacher should design his strategies, methods of teaching and activities of the curriculum in an inspired way, which does not end up in isolated, artificial settings such as tests, but leaves sustainable traces in students' daily lives.

The Education for Sustainable Development is based on the idea that communities and educational systems within communities need to integrate their sustainability efforts. As communities develop sustainability goals, local educational systems and programs can modify existing curricula or create new programs to reinforce those goals. ESD has become a key and/or integral component of technical and vocational education. Now in Egypt, we take in our consideration to implement the sustainability management in "development the curricula, Training the teachers, preparing the educational Equipment through the 2030 vision" (GMES, Egypt, 2017).

Science educators have struggled for decades with the question of how to design and evaluate curricula through which scientific knowledge does not end up in isolated, artificial settings such as tests, but leaves sustainable traces in students' daily lives. Sustainable development is a society project, and a political one, that cannot be defined and implemented without science, both because science has to play a huge role in the choice of technical solutions and because science isn't disconnected from society. Indeed, science is often seen as the objective and probably the most rational part of the culture. Even if driven by creativity, emotion or opinion too, science deals with rationality and the search of facts. It brings objective arguments and facts that fuel the reflection on social and economic phenomena, and allow going beyond the opinion debate, thus contributing to the ambition of rationality social sciences themselves pursue. Besides, the scientific approach or method could stimulate the same level of demand in the reasoning (Blumstein D. \& Saylan, C., 2007, 296). 
From an education perspective, Ospina (2000) refer that developing sustainable development in science can be viewed as (as cited in Holbrook, J., 2009, pp. 5, 6):

- Place a system of values and ethics in the science curricula preparation and pedagogy, in order to connect the science curricula with the society sustainable development requirements.

- Encouraging a meeting of disciplines, a linking of knowledge and of expertise, and to render our understanding more integrated, contextualized, and so, in turn, to open up new horizons for justice and equality (equity).

- Encouraging lifelong learning, starting at the beginning of life and grounded in life - one based on a passion for a radical transformation of society and a change in the moral character of society. This could be implemented in science through meaningful aesthetic understanding to its phenomena and concepts.

- Advancing new conceptions rooted both in traditional scientific rationality and in popular beliefs and consciousness, drawing on these as a source of human understanding and a pointer to collective wisdom. This could be implemented through activation of the affective domain in science learning.

- Ensuring the preparation of teachers according to ESD requirements, which could reflected on their classrooms practices and on their students acquiring to $\mathrm{SD}$ requirements.

- Ensuring the social and cognitive domains in learning which build the entire student's personality.

ESD (and related initiatives like sustainability education and sustainable pedagogy) raises some crucial questions such as: How can biology education as one of science disciplines actively contribute to the severe environmental, technological and scientific challenges of our time? How should biology teacher education meet these challenges? Our biology-teachers-to-become will meet students in class who can be encouraged to contribute to a sustainable future in society. During their 
training, teachers should be given possibilities to practice skills to promote sustainable development. Critical thinking about the sources of unsustainable actions and positive examples of sustainable ways to go about with resources is important, but not sufficient (Sterling, 2001, p.94).

\section{For the above to be put into place, Biology Education for sustainable education} needs to be viewed as a means to:

- $\quad$ Promote a culture of citizenship and give value to biosocial actors (such as non-governmental organizations and other sub-groups).

- Valorize aesthetics, the creative use of the imagination, notion, integration between the knowledge and their aspects on our life.

- Search the beauty in biology to increase the passion to learn it, through many inspired activities, questions or projects.

- Assert the importance of biological issues in local communities and their ties to the entire Earth and indeed with the universal.

- Seek Aesthetic understanding, to anticipate, imagine and to contextualize our knowledge in biology teaching and learning in a meaningful way, which could help students to keep knowledge and retain it effectively.

- Develop to the maximum, the potential of students, throughout their lives, so that they can achieve self-fulfillment and full self-expression with the collective achievement of a viable future; effect change in value systems, behavior patterns and lifestyles necessary to achieve sustainable development, and ultimately democracy, security and peace.

- Disseminate the biological knowledge and skills necessary to foster sustainable production and consumption patterns and to improve the management of natural resources, agriculture, energy and industrial production through biology education integrated with other science disciplines, and prepare teachers, whom have the ESD requirements to do that. 
- However, attitudes towards integrating sustainability education in biology education were very positive. Pre- and in-service teachers will be openminded and interested in learning about how to integrate Education for Sustainable Development into their biology classes.

Based on the views discussed above on the benefits of aesthetic understanding and education for sustainable development, the present study investigates the effectiveness of oriented- training program based on aesthetic understanding and ESD requirements to biology teachers through action research to investigate its impact on their classroom practices. The researcher benefited from reviewing the theoretical framework in preparing the research tools.

\section{- Research Hypotheses}

To solve the research problem and answer the research questions, the researcher tested the following hypotheses:

1. There is a statistically significant difference between the mean score of the research group teachers' awareness to the aesthetic understanding concepts and ESD requirements in the pre- and post- administration of the mind map in fever of the post results.

2. There is a statistically significant difference between the mean score of the research group in the pre- and post- administration of the aesthetic understanding questionnaire in fever of the post results.

3. There is a statistically significant difference between the mean score of the research group in the pre- and post- administration of the ESD questionnaire in fever of the post results.

- Methodology

To answer the questions of the study and check the validity of its hypothesis, the following procedures were followed:

First: Literature and related studies in aesthetic understanding, and ESD are reviewed to prepare the study learning and assessment materials. Some researches were revised

- Second: Preparing the Learning materials: 
The researcher prepared the leaning material (Hands-on) and teaching guide to the high-level biology teachers according to the following steps:

a) Illustrating the aim of the oriented program, detecting its objectives, and its anticipated impact on the biology teachers' performances.

b) Developing a brief theoretical framework on "Aesthetic understanding and ESD principals" and illustrate the way to apply through action- plan project in the biology curriculum.

c) Illustrating the general information of the program, which are: (1-Its name: "Oriented program for secondary- stage Biology- teachers based on Aesthetic understanding and Educational Sustainable Development requirements". 2- The required hours: are about four-hours weekly per 5 weeks. 3-The content which is: "Introduction, aesthetic understanding principals, ESD principals, aesthetic understanding strategies and the way to apply in biology, ESD requirements pedagogies and ways to apply them in biology curriculum, Model for implementing the aesthetic understanding philosophy and ESD strategies, and Other sources of enrichment).

d) Detecting the program activities and the instructions needed to apply them during each session.

e) Detecting the learning sources, which are (Teachers hands- on, classroom practices, peer learning and enrichment sources).

f) Methodology: There is mix of strategies and methods that used to implement the program goals, like (Active lecture method- Discussion methodAnalogies strategy- Storytelling method- peer learning- cooperative learninginquiry- problem- based project).

g) Assessment and Evaluation: Teachers assessed through qualitative and quantitative instruments that illustrated clearly in appendixes $(3,4,5)$

h) Illustrating the research action plan: help teachers to reflect on applying the program objectives in their classrooms. 


\section{Third: preparing the assessment materials:}

\section{a) Qualitative instruments}

\section{- Mind Maps}

The aim of this was to probe for the cognitive organization that the teachers had before and after involving in the oriented program. The mind map rubric analyzed the number of valid cross-links among concepts and the number of hierarchal levels, which are (Structure, Exploratory, Communication, Connections between Sections, Extent of Coverage) with four levels; level 1= 10 degrees, level $2=15$ degrees, level $3=20$ degrees and level 4= 25 degrees in which each criterion has 5 degrees. The reliability and validity of the rubrics were determined by having a second rater to be able to use (Appendix 6). As for the validity, experts helped decide on the construct validity. The lowest total score on the mind map was 10 while the highest was 25 degree.

\section{- Project base learning Form}

A tool to assess the ability of biology teacher after learning the oriented program to design a topic in biology curriculum in a project form according to the aesthetic and ESD pedagogy requirements. It consists of three parts: (Reflection on Project Form, The reflective log and Action Plan Guide form). Reliability and validity of the form's dimensions items detected statistically after applying it on 25 biology teachers in two international schools in Egypt. The next table shows that all dimensions have good fit statistics, given that the threshold value of the comparative fit index (CFI) is equal to or more than 0.97 and the root mean square error of approximation (RMSEA) is less than 0.08. The lowest total score is 20 and the highest is 50 degrees). The degrees divided as follow: 
Table (2) the validity of PBL form's dimensions

\begin{tabular}{|c|c|c|c|c|c|}
\hline PBI dimensions & $\chi^{2}$ & $d f$ & P & RMSEA $^{\text {a) }}$ & CFI \\
\hline $\begin{array}{c}\text { Reflection on Project } \\
\text { Form }\end{array}$ & 19.381 & 24 & 0.022 & 0.075 & 0.986 \\
\hline $\begin{array}{c}\text { Action Plan Guide form } \\
\text { The reflective log }\end{array}$ & 32.013 & 24 & 0.010 & 0.070 & 0.984 \\
\hline $\begin{array}{c}\text { (Making an action plan) } \\
\text { Total }\end{array}$ & 14.483 & 24 & 0.043 & 0.072 & 0.991 \\
\hline
\end{tabular}

Reflection on Project Form: in which teachers design a project form questions; to get students to begin thinking about their project, through aesthetic understanding, real world problem, community they will cooperate with, knowledge needed and their project members. (5-10 degrees according to the teacher's ability to design questions helped his students to detect a biological problem and detect their plan to solve it).

Action Plan Guide form: This is intended to teachers' students to clarify what they want to do and how to do it to solve their biological problem that has detected through the last step. Teachers should enhance their students to their initial feeling about their project, orient questions helped them to select a project, detect their ways to apply, community cooperation ships, their project members difficulties and how they will deal with it in a critical thinking). (10-30 degree to the Action plan guide form for explaining the reasons of selecting specific biological problem in the last step to be solved, to put their plan in action).

The reflective log (Making an action plan): a form designed by the biology teachers to allow students to record their feelings of the project, illustrating the way the project was introduced and developed in the community. The progress of the project, including the challenges and successes along the way should be noted. As far as possible students should comment on what took 
place each time they entered the field. The $\log$ is intended to record their feelings, their observation, their actions, the systematic process and the outcomes before; during and after the project and the ways they deal with the discipline issues). The log should include as well the feelings and the actions of the other participants. (5-10 degrees according to the ability of biology teacher to design a form help his students, to reflect on their project and spoke about how change is possible, despite the challenges).

\section{- Reflection Questionnaire (RQ):}

Reflection is "the process of critically assessing the content, process, or premise(s) of efforts to interpret and give meaning to an experience". Open-ended questions developed to document the teachers' views on how they perceived their experience in developing action research in aesthetic understanding and ESD. After a pilot study, questions reworded for better clarity. Responses to the questions were analyzed qualitatively in order to identify the underlying themes. It consists of three questions, each one assessed according to 4 criteria (Depth of reflection, required component, structure and Evidence\& practice). Each criterion has 20 degrees; (Unacceptable 0 degree, Minimal 1-5 degrees, sufficient 6-10 degrees and Superior 11-20 degree) with zero lowest degree and 80 highest degrees to each question. The criteria were putted by the author depending on the last literature, and examined by a second rater to put in its final shape (Appendix 6) as follows:

1. How do you view the collaborative action research experience in which you were involved?

2. How did your engagement in action research influence you personally?

3. How did your engagement in action research influence you professionally? 


\section{b) Quantitative instruments}

\section{- Aesthetic understanding questionnaire}

This questionnaire is addressed to biology teachers in the light of previous studies. These studies were numerous like: Hobbs\& Kelly (2017), Metha (2016), McIntyre\& Hobson (2015), Quay (2013), Song (2010), Girod (2007) \& Wickman (2006) to measure teachers' aesthetic understanding to science in general and biology specifically. The referees were asked to assess the items reliability in terms of clarity, suitability for the study's purposes and the appropriateness of the classification. The referees' comments and suggestions led to the omission of several items, the rephrasing of others and the merging of a number of items. The final version of the questionnaire (Appendix 3) was composed of two parts: the first one is 16 essay form questions with 5 -points responses scale $(1=$ no, $2-5=$ increasing gradations of frequency or quality of experience). The lowest degree for the first part is 16 and the highest one is 80 degrees according to their experience responses. The second one is 21 likert-scale questions as $(1=$ no, $2-3=$ increasing gradations of frequency or quality of experience according to the positivity or negativity of the statement, Agree, Neutral, disagree). The lowest degree is 21 degree and the highest one is 63 degree, with a total 37 lowest degrees and 143 degree. Reliability coefficients of the aesthetic understanding questionnaire dimensions items determined by the judgment of experts in science curricula at Ain-shams University. And to check its face validity it applied on a 50 random sample of biology teachers, The statistical package (SPSS) was used to check it in which, Cronbach's alpha was $=0.86$ and internal consistency was $=$ 0.73 , which indicate that it has a significant at the level of $(0.01)$.

- Biology Teachers' Awareness of Education for Sustainable development questionnaire:

This questionnaire was developed in the light of previous studies. These studies were numerous like Tolppanen (2015), Uitto \& Saloranta (2015), Stuckey, Hofstein, Mamlok-Naaman\& Eilks (2013), Uitto \& Saloranta. (2011), Uitto \& Saloranta (2010), Pepper \& Wildy (2008) to elicit the prospective teachers' 
perceptions about Education for sustainable development (ESD) and their awareness of the SD issues - cultural diversity, renewable energy and equity. The questionnaire first form was compiled from two parts; the first one is a list of 61 statements divided into five categories (domains). They were the concept of SD, cultural diversity, renewable energy and equity and pedagogy for ESD, while the second part is one essay (open -ended question) question. The referees were asked to assess the items reliability in terms of clarity, suitability for the study's purposes and the appropriateness of the classification. The referees' comments and suggestions led to the omission of several items, the rephrasing of others and the merging of a number of items. The final version of the questionnaire (Appendix 4) was composed of two parts; the first one consists of 59 items relevant to teachers' perceptions about SD: 1 . the concept of SD-16 items; 2 . Cultural diversity -6 items; 3 . Renewable energy -8 items; and 4. Equity-11 items and 5. The teaching practices for sustainable development- 18 items in a 5-point Likert scale responses: (5) strongly agree; (4) agree; (3) unsure; (2) disagree; and (1) strongly disagree.

The second part is an essay question of 5 -point response scale $(1=$ no, $2-5=$ increasing gradations of frequency or quality of experience). The teachers were asked how often they considered different dimensions of sustainability (ecological, economic, social, and cultural) in their teaching: "Evaluate how often the teacher considers the issues of ESD in his teaching. The teaching methods are free depending on the topic that he/ she choose and its nature. Reliability coefficients of the attitude scale and ESD teaching practices were determined by the judgment of experts in science curricula at Ain-shams University. And to check its face validity it applied on 50 random biology teachers, Then a statistical package (SPSS) was used to check it, Cronbach's alpha was $=0.91$ to all domains and internal consistency was $=0.82$, $0.84,0.70,0.83$ and 0.74 respectively to each domain which mean that it has a significant at the level of $(0.01)$.

These values indicate that the present questionnaire (Appendix 4) was consistent and reliable for the purposes of collecting the data needed for the current 


$$
\begin{aligned}
& \text { د/ أماني محمد عبدالحميد أبو زيد }
\end{aligned}
$$

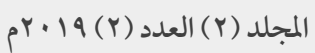

study. The questionnaire was distributed to the research group teachers and they were asked to indicate the degree to which they perceive the items listed in the questionnaire. The participants were also instructed to specify their gender and specializations, as these two variables were required to answer the second part of the study.

\section{- Results and discussion}

1- To answer the first question: What is the biology teachers' perception of aesthetic understanding and ESD?

A blank sheet was given to the participants to construct their mind maps of aesthetic understanding and ESD in a time limit of twenty minutes before studding the oriented program and involving in the action research. The same task was done again after studding the training program. Participants were graded using the proposed grading system in this study. A Wilcoxon Signed Ranks Test (non- parametric statistical SPSS tool) was used to assess the significance of the biology teachers' awareness to the aesthetic understanding concepts and Education for sustainable development requirements in the pre and post- results after the action research involvement program. The criteria of the mind map putted by the author according to the last literatures that illustrated in details in (appendix 6), and the results shown in the following table:

Table (3) comparison of pre and post results of Biology Teachers' Reponses in Mind Map
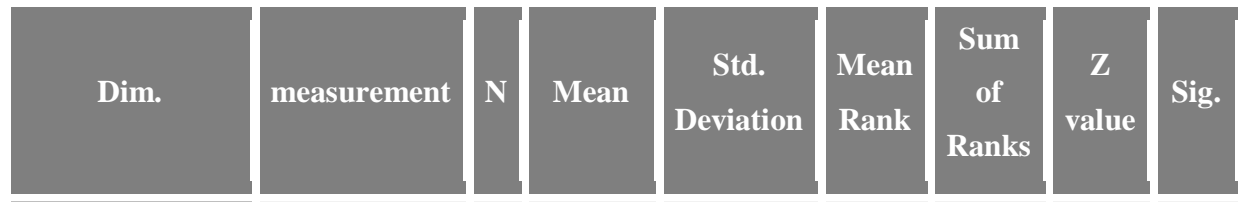

Depth of
Reflection

\begin{tabular}{|l|}
\hline pre \\
\hline post \\
\hline pre \\
\hline post \\
\hline
\end{tabular}

5

1.2000

.4472

0

0

$5 \quad 3.6000$

.8944

3

2.06

0.05

15

Exploratory

\begin{tabular}{|l|l|}
\hline 5 & .8000 \\
\hline 5 & 3.4000 \\
\hline
\end{tabular}

.8367

0

0

.5477

3

2.07

0.05 

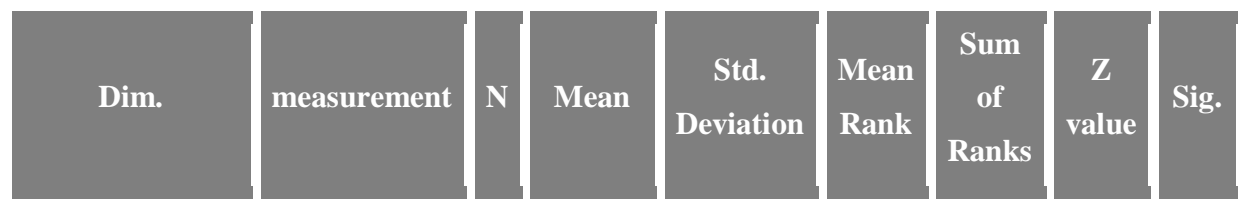

\section{Communication}

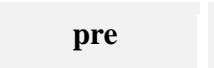

$5 \quad .2000$

.4472

0

0

Communication

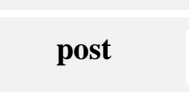

\begin{tabular}{|c|}
\hline Connections \\
between \\
Sections \\
\hline
\end{tabular}

\begin{tabular}{|l|}
\hline pre \\
\hline post \\
\hline
\end{tabular}

$5 \quad 3.0000$

1.0000

3

$2.04 \quad 0.05$

15

\begin{tabular}{|l|l|l|l|l|}
5 & .2000 & .4472 & 0 & 0 \\
\hline
\end{tabular}

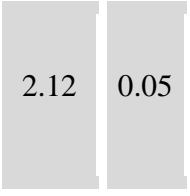

\begin{tabular}{|c|}
\hline Extent of \\
Coverage \\
\hline Total \\
\hline
\end{tabular}

\begin{tabular}{|c|}
\hline pre \\
\hline post \\
\hline pre \\
\hline post \\
\hline
\end{tabular}

5

$5 \quad .4000$

$5 \quad 2.8000$

.4472

\begin{tabular}{|l|l|}
\hline 5 & 2.8000 \\
\hline 5 & 15.2000 \\
\hline
\end{tabular}

\begin{tabular}{|l|l|}
\hline 2.3875 & 0 \\
\hline 2.7749 & 3 \\
\hline
\end{tabular}

0

$2.03 \quad 0.05$

15 
This entails that the participants' involvement in the action research had a positive impact on their conceptual knowledge construction on aesthetic understanding and ESD, which was better at the end of the research than at the beginning. The number of concepts and the dimensions represented with a statistically significant difference at the level of (0.05) between the mean scores of teachers in the pre- and post-results of mind map according to the Z- value to each criterion. This reflects the theoretical framework "ExConTra" as it particularly emphasizes the conceptualizing and constructing components of the program. In the pre-concept mapping analyses, the teachers lacked the concept of mind maps, and the way to construct it. In addition to the poor acquirement to the ESD and aesthetic understanding concepts, this reflected in their results. This all changed in a statistical significance in the post- data after the involvement in the action research that teachers were engaged in that provided for meaningful experiential learning, as part of the "ExConTra" model, on the key concepts and values of various Aesthetic dimensions and ESD dimensions. This finding aligns with what a study indicated that when professional development is content-focused, connected to other aspects of teachers' lives and coherent; it is more likely to have positive impact on teachers' knowledge and skills than less coherent experiences, aligns with Fun and Maskat (2010) study. (This is what the action research projects seemed to advocate as it added meaning to biology teachers responsibilities and roles. According to Makrakis and KostoulasMakrakis (2012) in their ExConTra model, for learners to make meaning, either individually and/or shared, they need to reflect on their own experiences, leading them to develop more abstract understandings of their experiences (conceptualizing).

2- To answer the second question: What is the context of oriented program based on the aesthetic understanding and EDS' requirements pedagogical practices? Program based on aesthetic understanding philosophy and ESD requirements was oriented according to the aesthetic understanding philosophy in educational context and ESD pedagogy, and mainly adopt its objectives and teaching methodologies to aesthetic understanding, and hands-on and involve the participants in practices that help them 
to increase their meaningful aesthetic understanding and gain ESD requirements. The main method in revising the program was by the "infusion approach" as mentioned in the procedure point. The program was a four-hours weekly per 5 weeks offered in the second/ spring term in the academic year 2017/2018, this illustrated in details in appendix (2).

3- To answer the third question: What is the effectiveness of the oriented program to develop the biology teachers' aesthetic understanding? Aesthetic understanding questionnaire was addressed to biology teachers to measure their aesthetic understanding in science generally and biology specifically, this questionnaire applied before studding the oriented program and once again after the action plan program. A dependent $\mathrm{t}$-test analysis using SPSS shows that the final mean is greater than the initial mean. This entails that the participants' involvement in the oriented program through action research had a positive impact on their aesthetic understanding to the biology concepts. The mean and standard of deviation of the pre- and post-aesthetic understanding questionnaire analyzed by Wilcoxon Signed Ranks Test (nonparametric SPSS tool) as follows:

Table (4) comparison of pre and post results of Teachers' Aesthetic understanding questionnaire
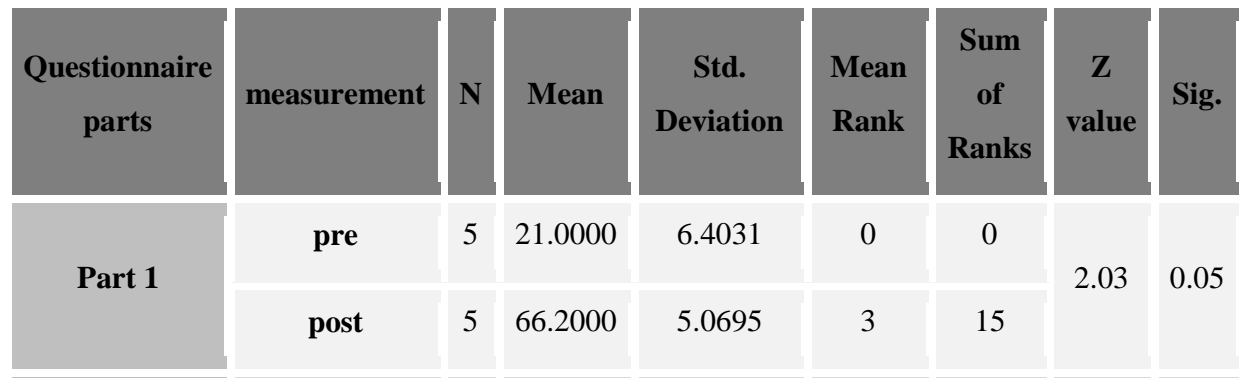

Part 2

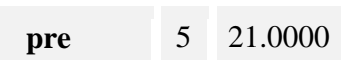

$$
\text { pre }
$$

$$
\text { post }
$$

$$
5
$$

$$
\text { pre }
$$

$$
\text { post }
$$

$5 \quad 53.4000$

5

52.2000

$$
6.4031
$$

0

3

5.0695
0

$2.03 \quad 0.05$

15

0

$2.03 \quad 0.05$

\begin{tabular}{|l|l|}
\hline 3.0496 & 0 \\
\hline 1.3038 & 3 \\
\hline
\end{tabular}

15 
The table shows that there is statistical significance differences between the pre and post results at the level of (0.05) to the (2.03) $\mathrm{Z}$ value to each part of the questionnaire, which illustrate the effectiveness of the oriented program for biology teachers to increase their acquisition to the aesthetic understanding of science generally and Biology specifically. Moreover, this aligns with Pugh and Girod (2007) whom offered pedagogical strategies, derived from Dewey's aesthetic theory, useful in scaffolding aesthetic science learning. And Song (2010) study which described that the integration of experience with mind and emotion is effective in converting the biology teachers' perspectives from seeing the biology as an abstract subject to inspired one full of aesthetic concepts that could change their life and their students' life. In addition, Murphy (2014) confirmed that action oriented program for teachers increased their aesthetic experience and broadening their intellectual and cultural horizons, which reflect positively on their students.

4- To answer the fourth question: What is the effectiveness of the oriented program to develop the education for sustainable development requirements for biology teachers? Biology Teachers' Awareness of Education for Sustainable development questionnaire was addressed to biology teachers to measure their acquisition to the education for sustainable development requirements, this questionnaire applied before studding the oriented program and once again after the action plan program. A dependent t-test analysis using SPSS showed that the final mean is greater than the initial mean. This entails that the participants' involvement in the oriented program through action research had a positive impact on the biology teachers' acquisition to the education for sustainable development requirements. Wilcoxon Signed Ranks Test (non- parametric SPSS tool) calculates the mean and STDV of the pre- and postaesthetic understanding questionnaire's results as follows: 
Dr. Abuzied, Amany Mohamed

Volume (2) No. (2) 2019

Table (5) Comparison of pre and post results in Education for Sustainable development questionnaire

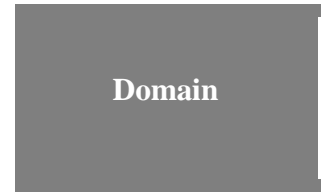

Teachers' perceptions in the concept of SD domain items:

Teachers' perceptions
in the cultural
diversity domain
items:

Teachers' perceptions
in the renewable
energy domain items:

Prospective teachers'
perceptions in the
equity domain items:

Prospective teachers' perceptions in the teaching for sustainable development:
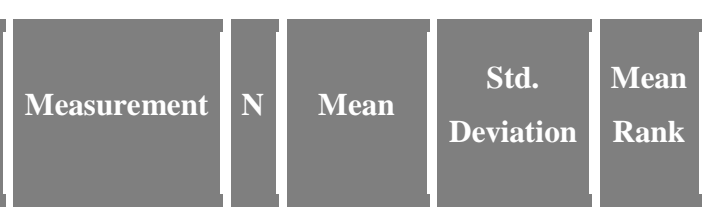

Sum
of
Ranks
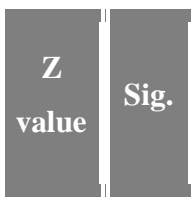

Pre

$5 \quad 62.0000$

1.2247

0

$2.03 \quad 0.05$

\begin{tabular}{|l|l|l|l|l|l|} 
Post & 5 & 78.8000 & .8367 & 3 & 15 \\
\hline
\end{tabular}
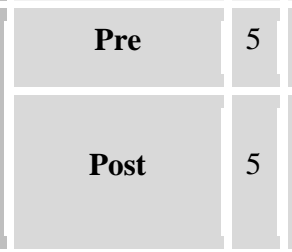

17.2000

\subsection{8}

0

0

$5 \quad 29.8000$

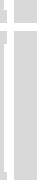

Pre

$5 \quad 17.8000$

2.3875

0

0

$2.02 \quad 0.05$

15

\begin{tabular}{|l|}
\hline Pre \\
\hline Post \\
\hline
\end{tabular}

\begin{tabular}{|l|l|}
\hline 5 & 32.0000 \\
\hline 5 & 47.8000 \\
\hline
\end{tabular}

\begin{tabular}{|l|l|}
\hline 4.6904 & 0 \\
\hline 1.6432 & 3 \\
\hline
\end{tabular}

0

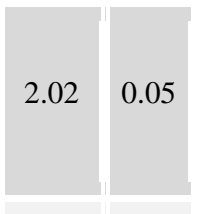

Pre

$5 \quad 45.8000$

2.8636

0

$2.03 \quad 0.05$

\begin{tabular}{|l|l|l|l|l|l|}
\hline Post & 5 & 71.2000 & 2.3875 & 3 & 15 \\
\hline
\end{tabular}

Total

\begin{tabular}{|l|l|l|l|l|l|l|l|}
\hline Pre & 5 & 174.8000 & 6.6483 & 0 & 0 & \\
\hline Post & 5 & 253.8000 & 4.3243 & 3 & 15 & & \\
\hline
\end{tabular}




$$
\begin{aligned}
& \text { د/ أماني محمد عبدالحميد أبو زيد }
\end{aligned}
$$

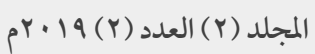

The table shows that there are statistical significance differences between the pre and post results at the level of (0.05) according to " $Z$ " value to each dimension of the questionnaire, which illustrate the effectiveness of the oriented program for biology teachers to increase their awareness of SD and the ESD requirements. However, this aligns with Blumstein \& Saylan (2007) whom assured that the learning context could affect gaining the ESD requirements. In addition, Murphy (2014) study confirmed that action oriented program for teachers increased their acquisition to the program objectives and reflected on their responses and their perspectives instead of the theoretical vision.

5- To answer the fifth question: How do biology teachers perceive their experiences through action research to develop meaningful aesthetic understanding in teaching biology? First; Biology teachers in this study developed action plans measured by the (project- based learning form) that started by detecting one topic in biology identifying tools of aesthetic understanding focus of an ESD pedagogies, then going through developing action plans, data collection and finally reaching results, suggestions and final reflections. The teachers' actual plan results illustrated through the following table:

Table (6) Project- based learning form of Biology teachers' results

\begin{tabular}{|c|c|c|c|c|c|}
\hline Q1Criteria & $\begin{array}{c}\text { First } \\
\text { teacher A, } \\
\text { Mr. } \\
\text { Ahmed } \\
42 \mathrm{y}\end{array}$ & $\begin{array}{c}\text { Second } \\
\text { teacher B, } \\
\text { Mr. } \\
\text { Mamdouh } \\
\mathbf{4 4 y}\end{array}$ & $\begin{array}{c}\text { Third } \\
\text { teacher C, } \\
\text { Miss } \\
\text { shaimaa } \\
\text { 35 y }\end{array}$ & $\begin{array}{c}\text { Fourth } \\
\text { teacher, } \\
\text { Ms. Marie } \\
\mathbf{5 6 y}\end{array}$ & $\begin{array}{c}\text { Fifth } \\
\text { teacher, } \\
\text { Miss } \\
\text { Nahla } \\
\mathbf{2 5} \text { y }\end{array}$ \\
\hline $\begin{array}{l}\text { 1-Reflection on } \\
\text { project form } \\
(5-10 \text { degrees })\end{array}$ & 6 & 7 & 7 & 5 & 6 \\
\hline $\begin{array}{c}\text { 2-Action plan Guide } \\
\text { Form } \\
\text { (10-30 degrees) }\end{array}$ & 25 & 26 & 27 & 24 & 27 \\
\hline $\begin{array}{c}\text { 3-The Reflective log } \\
\text { (5-10 degrees) }\end{array}$ & 7 & 7 & 5 & 5 & 7 \\
\hline Sum/50 & 38 & 40 & 39 & 34 & 40 \\
\hline
\end{tabular}


The last table illustrated that the teachers respond positively in their teaching practices according to their aesthetic understanding and acquiring the education for sustainable development requirements, this illustrated the importance of the action research in connecting the theoretical knowledge with the actual practicing in class.

Second: A reflective questionnaire with open-ended questions was designed to investigate biology teachers' experiences while developing their action plan projects. Analysis of teachers' responses required a coding process based on the qualitative findings. The main purpose of the analysis was not to quantify data but to find themes and criteria putted by the author across teachers' responses. The criteria putted by the author to each question criterion are $(0$ degree $=$ unacceptable points, $1-5$ degrees $=$ minimal points, $6-10$ degrees $=$ sufficient points, $11-20$ degrees $=$ superior points $)$. This analyzed as shown in the following table:

Table (7) Reflective questionnaire of Biology teachers' perspectives results

\begin{tabular}{|c|c|c|c|c|c|}
\hline Q1 Criteria & $\begin{array}{c}\text { First } \\
\text { teacher } \\
\text { Mr. } \\
\text { Ahmed } \\
\mathbf{4 2} \mathrm{y}\end{array}$ & $\begin{array}{c}\text { Second } \\
\text { teacher Mr. } \\
\text { Mamdouh } \\
\mathbf{4 4 y}\end{array}$ & $\begin{array}{c}\text { Third } \\
\text { teacher } \\
\text { Miss } \\
\text { Shaimaa } \\
\mathbf{3 5} \mathbf{y}\end{array}$ & $\begin{array}{c}\text { Fourth } \\
\text { teacher, } \\
\text { Ms. } \\
\text { Marie } \\
56 y\end{array}$ & $\begin{array}{c}\text { Fifth } \\
\text { teacher, } \\
\text { Miss } \\
\text { Nahla } \\
25 \mathrm{y}\end{array}$ \\
\hline $\begin{array}{l}\text { 1-Depth of } \\
\text { Reflection }\end{array}$ & 15 & 16 & 18 & 15 & 19 \\
\hline $\begin{array}{l}\text { 2-Required } \\
\text { Components }\end{array}$ & 17 & 18 & 18 & 15 & 18 \\
\hline 3-Structure & 19 & 19 & 19 & 18 & 19 \\
\hline $\begin{array}{l}\text { 4-Evidence and } \\
\text { Practice }\end{array}$ & 17 & 18 & 18 & 15 & 18 \\
\hline Sum/80 & 68 & 71 & 73 & 63 & 74 \\
\hline Q2 Criteria & $\begin{array}{c}\text { First } \\
\text { teacher A, } \\
\text { Mr. } \\
\text { Ahmed }\end{array}$ & $\begin{array}{c}\text { Second } \\
\text { teacher B, } \\
\text { Mr. } \\
\text { Mamdouh }\end{array}$ & $\begin{array}{c}\text { Third } \\
\text { teacher C, } \\
\text { Miss } \\
\text { shaimaa }\end{array}$ & $\begin{array}{c}\text { Fourth } \\
\text { teacher, } \\
\text { Ms. } \\
\text { Marie }\end{array}$ & $\begin{array}{c}\text { Fifth } \\
\text { teacher, } \\
\text { Miss } \\
\text { Nahla }\end{array}$ \\
\hline $\begin{array}{l}\text { 1-Depth of } \\
\text { Reflection }\end{array}$ & 18 & 18 & 18 & 17 & 18 \\
\hline $\begin{array}{l}\text { 2-Required } \\
\text { Components }\end{array}$ & 18 & 17 & 18 & 18 & 19 \\
\hline 3-Structure & 18 & 18 & 19 & 17 & 19 \\
\hline $\begin{array}{c}\text { 4-Evidence and } \\
\text { Practice }\end{array}$ & 16 & 18 & 19 & 15 & 19 \\
\hline Sum/80 & 70 & 71 & 74 & 67 & 75 \\
\hline
\end{tabular}




$$
\begin{aligned}
& \text { د/ أماني محمد عبدالحميد أبو زيد }
\end{aligned}
$$

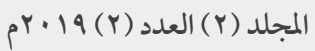

\begin{tabular}{|c|c|c|c|c|c|}
\hline Q3Criteria & $\begin{array}{c}\text { First } \\
\text { teacher A, } \\
\text { Mr. } \\
\text { Ahmed }\end{array}$ & $\begin{array}{c}\text { Second } \\
\text { teacher B, } \\
\text { Mr. } \\
\text { Mamdouh }\end{array}$ & $\begin{array}{c}\text { Third } \\
\text { teacher C, } \\
\text { Miss } \\
\text { Shaimaa }\end{array}$ & $\begin{array}{c}\text { Fourth } \\
\text { teacher, } \\
\text { Ms. } \\
\text { Marie }\end{array}$ & $\begin{array}{c}\text { Fifth } \\
\text { teacher, } \\
\text { Miss } \\
\text { Nahla }\end{array}$ \\
\hline $\begin{array}{l}\text { 1-Depth of } \\
\text { Reflection }\end{array}$ & 18 & 18 & 18 & 17 & 18 \\
\hline $\begin{array}{l}\text { 2-Required } \\
\text { Components }\end{array}$ & 18 & 18 & 18 & 18 & 19 \\
\hline 3-Structure & 18 & 19 & 19 & 17 & 19 \\
\hline $\begin{array}{c}\text { 4-Evidence and } \\
\text { Practice }\end{array}$ & 16 & 18 & 19 & 15 & 19 \\
\hline Sum/80 & 70 & 73 & 74 & 67 & 75 \\
\hline Questions total 240 & 208 & 215 & 221 & 197 & 224 \\
\hline
\end{tabular}

From the above results, all the teachers had positive responses in the reflective questionnaire and had a positive attitude to the involvement in the action research, this show that the integration of the theoretical study with practicing forms a positive experience. The teachers' responses varied from one teacher to the other. However, it is noticed that the fourth teacher had a lowest degrees which could be due to the age agent, in whom she was the oldest one (56 years old), this in comparable with the fifth teacher whom was (25 years old). However, this could illustrate that the age could effect on the acquisition of the new experiences. This rule could not be generalized because the sample is small and do not represent all the society. In addition, there is no shown significance between the male and female responses as a sex agent in this action research and could not considered a general principle too. This could be due to "infusion approach" that permits to address aesthetic understanding and ESD pedagogies by teaching the topics with a different perspective and philosophy without changing the meaning and aim of the original version. This is linked to Reason (2007) study. Action research also played a significant role in this reflection through engaging and challenging the teachers, stimulating dialogue and social negotiation, learning by exploring and discovering then doing and reflecting and this assured by Makrakis (2011). 


\section{Moreover, these are examples of the teachers' responses in their reflective}

\section{questionnaire:}

First question: How do you view the collaborative action research experience in which you were involved? They all agreed on enjoying these experiences and enjoyed the collaborative ideas during the oriented program hands-on.

Second question: How did your engagement in action research influence you personally? According to the reflective questionnaire, the teachers explained how passion for the biology is reflected on them personally. Nahla said: "she enjoyed her students' enjoyment into the classroom, and started to reflect on many things in her life”. Ahmed argued: "If I lack of passion of biology, I'll don't particularly enjoy its teaching, I don't know, Although we're all suffering together from many restrictions in our life, reflection and aesthetic understanding change my life vision!". Shaimaa and Marie agreed on their benefits from their experiences in action research that reflected on their family positively". While Mamdouh said: "he interested in the action plan and teaching in this way, but there is no significance change in his life according to it, except that he try to contemplate about his life issues more".

Third question: How did your engagement in action research influence you professionally?

Teacher A, Mr. Ahmed emphasized the importance of teaching and learning through the powerful biological ideas, he said "I believe that we all suffering from abstract teaching although I believe that aesthetic and creative ideas change the way we think about the world. This emphasis was illustrated during teaching the "DNA transcription" topic in which I transform the topic to the idea of "DNA as war" between forces trying to denude and the resistance of the earth's surface and features. In addition, when I teach the photosynthesis topic, I described it as an "Tree from Asch" rather than simply the "photosynthesis process" as it was defined in the other classroom. These reflected on my students positively and they excited such way of teaching".

Teacher B, Mr. Mamdouh ensured the importance of helping students to see the world in a different vision through biology learning. He argued "I call it re-seeing. I 
asked my students to express everyday one issue they noticed in a different way in their life related to biology learning. The stories they tell are awesome!"

Teacher C, Miss shaimaa stated, "The world is an infinitely interesting place and I want my students to recognize that. During each of the instructional units, I used story-telling, relayed interesting statistics, and described the biggest and most dangerous natural phenomena (hurricanes, landslides...) in an effort to engender student wonderment of SD".

Teacher D, Ms. Marie emphasized the importance of personalizing experiences. For example, during the Cell unit she described how important it was to let students talk about their experiences in metabolism. She asked her students "imagine that you are a micro- robot injected in the body to check what happened to it during eating and starvation. Tell me your magic journey story", and commented that “If you do not let students link their own lives to learning you are missing a very effective teaching strategy." Recall Deweyan transaction where both person and world are changed because of transformative, aesthetic experience. To be so transformed, this required opportunities to personalize or "try on" new ideas, and the power they illuminate aspects of the world previously hidden, and this finally my students realize the importance of robots and technology and explore their body in a different perspective. Teacher E, Miss Nahla described her role as, "to model passion and enthusiasm for biology." she described two of her most memorable teachers and how they had taught her the importance of demonstrating passion. "I want my students to see me excited about biology because then they are more likely to also be excited about it." As an illustration of how these values were expressed in her classroom, the following illustrative example is provided. "On the first day of the photosynthesis unit in her classroom she took her students outside, had them lay on their backs in a circle and stared up into the sky.

The common significant similarities between the five teachers' classrooms were the instructional strategies employed by them. The teaching and learning biology for transformative, aesthetic experience could change their conceptual understanding 
emphasizing cognitive, rational beliefs, interesting about learning according to Aesthetic understanding and ESD pedagogy.

\section{Conclusion and Recommendations}

According to UNESCO's final report on UNDESD development (2014, p. 9), 'there is now an increased recognition at the international policy level that education is essential to advancement of sustainable development' and that the teacher is the beating heart of this process. The results of this study indicated that teacher's perspectives had high perceptions about the pedagogy of aesthetic understanding, concept of SD the related three issues in this study—cultural diversity, and equity and the requirement of ESD after striving during and after action plan. However, while the results align with the goals of the UNDESD for the individual, they do not specifically infer that the teachers' perspectives will be able to transfer these perceptions into practical activities and hence influence the lives of their future students in schools.

\section{Recommendations}

The significance of this study hinges upon the experiences of biology teachers engagement in action research. The research empowered the teachers to take the role of active participants in the research process and helped them develop and critically analyze and reflect on their own knowledge about teaching. To achieve this, the research recommended:

- Rethinking the efforts planned in biology teachers' preparation and performance development programs for in- service teachers in the light of aesthetic understanding and ESD requirements.

- New interdisciplinary postgraduate programs could be introduced to address this perspective. Furthermore, the government should join the Ministry of scientific research with the ministry of Education by collaborating with regional and international organizations to help the teachers take an active role in research. 
- Content analysis of both school and university textbooks in selected subjects such as chemistry, Geology, math and other subjects in order to explore how the aesthetic understanding and ESD pedagogy could be included in these textbooks.

- More studies about the teachers' perspectives for their teaching subject or discipline.

- Exploring school students' perceptions of different issues related to SD, and Use the ESD strategies to acquire it.

- Exploring the effectiveness of program based on aesthetic understanding of biology for biology teachers on increasing their students' conceptual knowledge of biological terms.

- Build training program for teachers -in service to infuse ESD core with their teaching.

- Further researches based on interdisciplinary approaches in science teaching. 


\section{References}

- Abrams, E.; Middleton, M. \& Benson, J. (2009). The development of motivation and academic identity for science learning in early adolescents from indigenous communities. In Proceeding of The National Association for Research in Science Teaching's Annual Conference, Anaheim, CA, USA, April, pp.17-21.

- Anderhag, P. (2017). "Taste for science: A Bourdieu-Pragmatism approach to interest, aesthetics and learning” Bellocchi, A., Quigley, C.\& Otrel, K.(Eds.), Exploring Emotions, Aesthetics and Wellbeing in Science Education Research, Cultural Studies of Science Education, v. 3, (pp. 3952). Switzerland: Springer International Publishing, DOI 10.1007/978-3319-43353-0.

- Anderhag, P.; Wickman, P. \& Hamza, K. (2015). Signs of taste for science: A methodology for studying the constitution of interest in the science classroom. Cultural Studies of Science Education, 10 (2), pp. 339-368.

- Anderson, R. \& Helms, J. (2001). The ideal of standards and the reality of schools: Needed Research. Journal of Research in Science Teaching, v.38, pp.3-16.

- Avraamidou, L. (2015). Stories of self and science: Pre-service elementary teachers' identity wok through time and across contexts. Pedagogies: An International Journal. doi:10.1080/15544 80X.2015.1047837.

- Beijaard, D.; Meijer, P. \& Verloop, N. (2004). Reconsidering research on teachers' professional identity. Teacher and Teacher Education, v. 20, pp.107-128.

- Blumstein D. \& Saylan, C. (2007). The failure of environmental education and how we can fix it. PLoS Biol, v.5, (5). doi:10.1371/journal. pbio.0050120.

- Briscoe, C. \& Wells, E. (2002). Reforming primary science assessment practices: A case study of one teachers' professional development through action research. Science Education, v, 86, pp.417-435. 
- Burmeister, M., \& Eilks, I. (2012). An example of learning about plastics and their evaluation as a contribution to Education for Sustainable Development in secondary school chemistry teaching. Chemistry Education Research and Practice, v.13, 93-102.

- Dahlin, B. (2001). The primacy of cognition - or of perception? A phenomenological critique of the theoretical bases of science education. In F. Bevilacqua, E. Giannetto \& Matthews, M. (Eds.). Science education and culture: The role of history and philosophy of science, pp.129-151. Dordrecht: Kluwer Academic Publishers.

- Darby, L. (2005). Science students' perceptions of engaging pedagogy. Research in Science Education, v. 35, pp. 425-445.

- Dewey, J. (2005). Art as experience. London: Penguin Books.

- Egypt National Review Report for Input to the 2016 HLPF (2016). The Arab Republic of Egypt National Voluntary Review on the Sustainable Development, Input to the 2016 High-level Political Forum (HLPF) on Sustainable Development. Retrieved on: www.sustainabledevelopment.un.org, at: 26/2/2018.

- Egypt National Review Report for Input to the 2016 HLPF (2016). The Arab Republic of Egypt National Voluntary Review on the Sustainable Development, Input to the 2016 High-level Political Forum (HLPF) on Sustainable Development. Retrieved on: www.sustainabledevelopment.un.org, at: 26/2/2018.

- Eijck, M. \& Roth, W. (2007). Improving Science Education for Sustainable Development. PLoS Biology, v. 5 (12), Pp.2763- 2769. Retrieved on: www.plosbiology.org.

- El-Zein, Jabbour; Tekce, Zurayk; Nuwayhid, Khawaja; Tell, Al Mooji; DeJong, Yassin, and Hogan (2014). Health and ecological sustainability in the Arab world: a matter of survival. NCBI. doi:10.1016/S01406736(13)62338-7. 
- Fun, C. and Maskat, N. (2010). Teacher-Centered Mind Mapping vs StudentCentered Mind Mapping in the Teaching of Accounting at Pre-U Level An Action Research, International Conference on Learner Diversity 2010. Procedia Social and Behavioral Sciences, v.7(C), 240-246.

- Girod, M. \& Wong, D. (2001). An aesthetic (Deweyan) perspective on science learning: Case studies of three fourth graders. The Elementary School Journal, v.102 (3), pp. 199-224.

- Girod, M. (2007). A conceptual overview of the role of beauty and aesthetics in science and science education. Studies in Science Education, v.43 (1), pp.38-61.

- Girod, M., Rau, C. \& Schepige, A. (2003). "Appreciating the beauty of science ideas: teaching for aesthetic understanding". Science Education, v. 87, pp.574-587.

- Girod, M.; Twyman, T. \& Wojcikiewicz, S. (2010). "Teaching and learning science for transformative, aesthetic experience". Journal of Science Teacher Education, v.21, pp.801-824.

- GMES (2017). Global Monitoring for Environment and Security in Africa -GMES \& Africa Ref: HRST/ST/G\&A/823/05.17. retrieved on: http://www.ossonline.org/en/global-monitoring-program-environment-security-africagmes-africa.

- Hadzigeorgiou, Y. \& Schulz, R. ( 2017). What Really Makes Secondary School Students "Want" to Study Physics? Education Science, November, v.7(4), pp. 84-90. doi:10.3390/educsci7040048

- Hadzigeorgiou, Y. (2017). Implication of R.S. Peters' Notion of Cognitive Perspective and its Implication for Science Education. Educational Philosophical Theory. Retrieved on: www.googlescholar.com. at 28/2/2018.

- Hadzigeorgiou, Y.; Kampouropoulou, M. \& Fokiali, P. (2015). The Aesthetic Appreciation of Nature in School Science Education: How Science Learning Can Help Raise Environmental Awareness. Scientific Research 
Publishing, Published Online May 2015 in SciRes. Retrieved on: http://dx.doi.org/10.4236/ce.2015.68077.

- Hadzigeorgiou, Y. \& Schulz, R. (2014). Romanticism and Romantic Science:

Their contribution to Science Education. Science and Education, v.23, pp.1963-2006.

- Hadzigeorgiou, Y. (2014). Reclaiming the value of wonder in Science Education.

In Wonder-Full Education: The Century of Wonder in Teaching and Learning across the Curriculum. Egan, K.; Cant, A.; Judson, G. (Edrs) Routledge: New York, NY, USA, pp.40-66.

- Hadzigeorgiou, Y. \& Stivaktakis, S. (2010). Encouraging Involvement with School Science. Curriculum Pedagogy, v. 5, pp. 138-162.

- Hadzigeorgiou, Y. (2005). On Humanistic Science Education, ERIC Document, ED506504. Retrieved on: http://files.eric.ed.gov/full-text/ED506504.pdf. at: $28 / 2 / 2018$.

- Hadzigeorgiou, Y. and Schulz, R. (2017). "What Really Makes Secondary School Students. Research gate, November. doi:10.3390/educsci7040084.

- Hammer, D. \& Schifter, D. (2001). Practices of inquiry in teaching and research. Cognition and Instruction, v.19, pp.441-478.

- Hidi, S.; Renninger, A. \& Krapp, A. (2004). Interest, a motivational construct that combines affective and cognitive functioning. In Dai, D. \& Sternberg, R. (Eds.).Motivation, emotion and cognition, (pp. 99-115), Mahwah: Erlbaum.

- Hine, G. (2013). The importance of action research in teacher education programs. Issues in Educational Research, v. 23 (2): Special Issue.

- Hobbs, L. (2012). Examining the aesthetic dimensions of teaching: Relationships between teacher knowledge, identity and passion. Teaching and Teacher Education, v. 28, pp.718-727.

- Hobbs, L. and Kelly L. (2017). "The Heart of the Educator: Aesthetic Experience Shaping Knowledge, Identity, and Passion”, Bellocchi, A., Quigley, C.\& Otrel, K.(Eds.), Exploring Emotions, Aesthetics and Wellbeing in 
Science Education Research, Cultural Studies of Science Education, V. 3, (pp. 5-82) Switzerland: Springer International Publishing, doi: 10.1007/978-3-319-43353-0.

- Hobbs, L. and Kelly L. (2015). "The Heart of the Educator: Aesthetic Experience Shaping Knowledge, Identity, and Passion”, Bellocchi, A., Quigley, C.\& Otrel, K.(Eds.), Exploring Emotions, Aesthetics and Wellbeing in Science Education Research. Cultural Studies of Science Education, v. 3, (pp. 5-82) Switzerland: Springer International Publishing. doi:10.1007/978-3-319-43353-0.

- Hobbs, L. (2013). Boundary crossings of out-of-field teachers: Locating learning possibilities amid disruption. In J. Langan-Fox \& C. L. Cooper (Eds.), Boundary-spanning in organizations: Network, influence, and conflict (pp. 7-28). New York: Routledge.

- Holbrook, J. (2009). Meeting challenges to sustainable development through science and technology education. Science Education International, v.20 (1/2), pp. 44-59.

- Howitt, C. (2007). Pre-service elementary teachers' perceptions of factors in a holistic methods course influencing their confidence in teaching science. Research in Science Education, 37 (1), pp.41-58.

- Hunsik, K.; Scharmann, L.; Kang, S. \& Noh, T. (2010). Cognitive conflict and situational interest as factors influencing conceptual change. Science Education, v.5, pp.383-405.

- Jakobson, B. \& Wickman, P. (2008). "Art in science class vs. science in art class: a Study in Elementary School. Education \& Didactique, v.2 (3), 141157.

- Kagan, S. (2011). “Art and Sustainability. Connecting Patterns for a Culture of Complexity. Lüneburg: Leuphana University.

- Klassen, S. \& Froese-Klassen, C. (2014). The role of interest in learning science through stories. Interchange, v. 45, pp. 133-151. 
- Koballa, T. \& Glynn, S. (2007). "Attitudinal and motivational constructs in science learning". In Abell, S. \& Lederman, N. (Eds.), Handbook of Research on Science Education, (pp. 80-120). Mahwah: Lawrence Erlbaum Associates, Publishers.

- Kraft, N. (2002). "Teacher research as a way to engage in critical reflection: A case study". Reflective Practicum, v. 3(2), pp.175-189.

- Lemake, J. (2001). Articulating communities: Sociocultural perspective on science education, Journal of research in science teaching, v.38, pp.296-316.

- Makrakis, V. \& Kostoulas-Makrakis, N. (2012). “The challenges of ICTs to online climate change education for sustainable development: The ExConTra learning paradigm", In S. A. Anwar (Ed.), Proceedings of the 5th Conference on eLearning Excellence in the Middle East - Sustainable Innovation in Education (pp. 594- 605). Dubai, UAE: Hamdan Bin Mohammed e-University.

- Makrakis, V. (2011). "ICT-enabled education for sustainable development: Merging theory with praxis", In M. Youssef \& S. A. Anwar (Eds.). Proceedings of the 4th Annual Conference on e-Learning Excellence in the Middle East 2011 ñ in Search for New Paradigms for Re-engineering Education (pp. 410-419), Dubai, UAE: Hamdan Bin Mohammed eUniversity.

- McIntyre, J. \& Hobson, A. (2015). Supporting beginner teacher identity development: External mentors and the third space. Research Papers in Education. doi: 10.1080/02671522.2015.1015438.

- Metha, R. (2016). Why teachers should care about beauty in science education? ResearchGate, June, 83-86.

Retrieved on: https://www.researchgate.net/publication/306013099.

- Mezirow, J. (2000). "Learning to think like an adult: Core concepts of transformation theory", In J. Mezirow \& Associates (Eds.), Learning as Transformation: Critical perspectives on a theory in progress (pp. 3-34). San Francisco, CA: Jossey-Bass. 
- Murphy A. (2014). Integrating Aesthetics into professional development for Teachers of English Learners. TESOL Journal, v. 5 (1), March, pp.82104.

- Neumann, A. (2006). Professing passion: Emotion in the scholarship of professors at research universities. American Educational Research Journal, v.43 (3), 381-424.

- Ostergaard, E., Dahlin, B. \& Hugo, A. (2008). Doing phenomenology in science education: a research review. Studies in Science Education, v.44 (2), pp.93-121.

- Ponte, P., Ax, J., Beijaard, D., \& Wubbels, T. (2004). Teachers' development of professional knowledge through action research and the facilitation of this by teacher educators. Teaching and Teacher Education, v.20 (6), pp.589-605.

- Potvin, P. \& Hasni, A. (2014). Interest, motivation and attitude toward science and technology at K-12 Levels: A systemic review of 12 years of educational research. Science Education, v. 50, pp. 85-129.

- Pugh, K. \& Girod, M. (2007). Science, Art, and Experience: Constructing a Science Pedagogy from Dewey's Aesthetics. Journal of Science Teacher Education, v.18, pp.9-27.

- Quay, J. (2013). More than relations between self, others and nature: outdoor education and aesthetic experience. Journal of Adventure Education and Outdoor Learning, v.13 (2), pp.142-157, doi: 10.1080/14729679.2012.746846.

- Reason, P. (2007). Education for ecology: Science, aesthetics, spirit and ceremony. Management Learning, v.38 (1), pp. 27-44.

- SDSN (2015). Getting Started with Sustainable Development Goals, Concept Note, and OECD 2015, retrieved on: http://unsdsn.org/wpcontent/uploads/2015/12/151211-getting-started-guide-FINAL-PDF-.pdf.

- Song, Y. (2010). Art in Nature and School. Journal of Aesthetic Education, v.44 (3), pp.96-108. 
- Sterling, S. (2001). Sustainable education. Re-visioning learning and change,

Devon: Green Books for the Schumacher Society. Retrieved on: www.books.google.com.eg at 27/2/2018.

- Summers, M. \& Childs, A. (2007). Student science teachers' conceptions of sustainable development: An empirical study of three postgraduate training cohorts. Science \& Technological Education, v.25 (3), pp.307327.

- Tytler, R. (2007). Re-imagining science education: Engaging students in science for Australia's future. Camberwell: Australian Council for Educational Research.

- UNESCO (United Nations Educational, Scientific and Cultural Organization) (2014). United Nations Decade of Education for Sustainable Development: Draft international implementation scheme. Retrieved on http://portal. UNESCO.org/education/en/ev.php 26/2/2018.

- UNESCO (2012). ESD Sourcebook: Learning \& Training Tools, No. 4. Paris, UNESCO. http://unesdoc. unesco.org/images/0021/002163/216383e.pdf.

- UNESCO (United Nations Educational, Scientific and Cultural Organization) (2004). United Nations Decade of Education for Sustainable Development: Draft international implementation scheme. Retrieved at :December 20, 2017, on: http://portal. UNESCO.org/education/en/ev.php.

- Van Zee, E.; Lay, D. \& Roberts, D. (2003). Fostering collaborative inquiries by prospective and practicing elementary and middle school teachers. Science Education, v. 87(4), pp.588-612.

- Wang, M.; Eccles, J. \& Kenny, S. (2013). Not lack of abilities but lack of choice: Individual and gender differences in choice of careers in science, technology, engineering and mathematics. Psychological Science, v. 2013, pp.1-6.

- “Want to Study Physics?", Education Sciences, November, v.7, pp.84- 95. doi:10.3390/educsci7040084. 
- Wellington, J. (2003). "Science education for citizenship and a sustainable future". Pastoral Care in Education, v.21 (30), pp.13-18.

- Wickman, P. (2006). Aesthetic Experience in Science Education: Learning and Meaning-Making as Situated Talk and Action, Mahwah, New Jersey: Lawrence Erlbaum Ass. 